\title{
Nutrition Status of Children Under-Five Years in Cassava Consuming Communities in Nambale, Busia of Western Kenya
}

\author{
Rhoda Azikoyo Nungo", Michael Wandayi Okoth, Samuel Kuria Mbugua \\ Department of Food Science, Nutrition and Technology, University of Nairobi, Nairobi, Kenya. \\ Email: *Azikoyo@yahoo.com, rhodanungo@gmail.com
}

Received February $2^{\text {nd }}, 2012$; revised April $24^{\text {th }}, 2012$; accepted May $4^{\text {th }}, 2012$

\begin{abstract}
A study was carried out to assess the nutritional status of under-five child population within cassava consuming community in Nambale of western Kenya. A structured questionnaire was used to collect socio economic data, 24-hour food re-call and anthropometric measurements. Data were analyzed using Statistical Package for Social Sciences. Descriptive statistics were used while Pearson's Chi Square and correlation coefficient (R) were used to test for statistical associations. A total of 320 households with 232 children participated. The findings showed nutrition status of children to be poor (<-2 SD), $26.6 \%$ were stunted, $13.9 \%$ underweight, and $10.1 \%$ were wasting. Malnutrition had reached its peak during the third year affecting boys more than girls despite a high mean score (9.2) for household dietary diversity. The findings established cassava utilization to be high $(94.3 \%)$ and mainly as "porridge, boiled roots and ugali". Eight staples including cassava were used for weaning and $66.4 \%$ of the children were fed three times daily. Cassava utilization was not a determinant of child nutrition status. Age of child and education level of head of household had strong but negative influence on child nutrition status, (Pearson's $\mathrm{R}=-0.207:-0.174$ ) indicating $>50 \%$ changes in stunting could not be attributed to age of child or education level of the head of household. Farm ownership was a strong positive determinant of nutrition status, Pearson's $\mathrm{R}=0.233$. This study has established that cassava cushions hunger and there is need to improve nutrient content.
\end{abstract}

Keywords: Cassava; Children; Nutritional Status; Utilization

\section{Introduction}

Nutritional status of children is determined by: age, gender, household characteristics, dietary intake and health status. These are influenced by underling determinants such as food security and community infrastructure including sanitation, safe water and local market conditions. Other factors include prices of related health inputs and available household resources [1]. Malnutrition which is poor nutritional status, can lead to disability, illness and death and jeopardize future economic growth by reducing the intellectual and physical potential of the entire population [2]. Globally malnutrition is estimated to contribute to over $50 \%$ of child deaths and 40 million are affected by vitamin A deficiency [3]. It is estimated that 190 million under-five year old children in developing countries are chronically malnourished and in Africa, $38.6 \%$ are stunted with $7.2 \%$ wasted [4].

In Kenya chronic and acute malnutrition, micronutri-

"Corresponding author. ent deficiencies and infectious diseases are prevalent, particularly among the rural populations and urban poor [5]. The Kenya government studies of 2008/2009, 2005/ 2006 compared to 2003 show percent increase in stunting (35:33:30), and wasting (7:6.1:6) [6]. Prevalence of severe malnutrition in Kenya at $7 \%$ is above the WHO/ UNICEF $2.3 \%$ acceptable rate expected in a healthy child population for developing countries. The Kenyan under-five mortality rate (U5MR) shifted from 97/1000 in 1990 to $120 / 1000$ in 2005 indicating vitamin A deficiency [7].

Cassava, (Manihot esculenta, Crantz) is very important in the diets of populations in Sub Saharan Africa and is the second staple after maize in western Kenya food systems [8]. Busia district ranked cassava first in both consumption and monetary value [9] and, high levels of malnutrition had been attributed to use of cassava, millet and sorghum [10]. Cassava contributes to calories, lacks vitamin A and has the lowest protein energy ratio (P:E), approximately $2 \%$ compared to other staple crops [11]. 
Protein is required for body building and repair of tissues while vitamin $\mathrm{A}$ is required by the body for vision, iron metabolism, skeletal growth, bone formation, gestation, placenta development, epithelial surface stability and integrity of the immune system [7]. The objective of the study was to assess nutritional status of under-five child population in cassava consuming community for later use in planning.

\section{Materials and Methods}

\subsection{Sampling}

Busia district was purposively selected as the study area due to the high poverty levels, persistent floods $[9,12]$, high cassava production and malnutrition. Multistage randomised sampling was used to select 1) one division from five divisions that grew cassava; 2) study sites from two locations within selected division. Fishers' equation [13] was used to calculate the least possible sample size: $\mathrm{n}=\mathrm{z}^{2}(\mathrm{pq}) / \mathrm{d}^{2}$. Where $\mathrm{n}=$ minimum sample size, $\mathrm{z}=$ the standard normal deviate at 1.96 for a confidence level of $95 \%, \mathrm{p}=$ rounded up proportion of malnourished children below five years in western Kenya [12], $q=$ the proportion of children below five years who are not malnourished in western Kenya, $d=$ the degree of accuracy desired set at 0.05 .

\subsection{Data Collection}

A structured questionnaire was administered to responsible household representatives. Data collected included: physical information of the respondent, gender, age and physical health status of child. Anthropometric measurements (weight and height) for children below 60 months, morbidity information and 24 hour food re-call using twelve food groups [14] was used to determine dietary diversity (DD) and food sources for protein, carbohydrates and vitamin A, staples for weaning, number of times children were fed in a day and Socio economic data.

\subsection{Statistical Analysis}

Child nutritional status data was analyzed using the National Centre for Health Statistics (NCHS) adapted by World Health Organization (WHO) as International reference standards. Anthropometric indices were calculated using the WHO 2005, Epiinfo Anthro growth standards to convert measurement indices. WHO Z-score cut-off point of $<-2$ SD was used to classify, low heightfor-age, low weight-for-height and low weight-for-age as moderate and $<-3$ SD severe under-nutrition. Both qualitative and quantitative approaches were used to analyze the data using SPSS, version 13.0 and Excel: frequencies, means, Pearson chi Square tests using cross tabulations and Pearson R using correlation coefficients significance $2 /$ t-tests were done to establish relationships between variables. Household dietary information was analyzed using the household dietary diversity score (HDDS) [14]. The FAO categories of dietary diversity scores applied in Mozambique [15] were used. Consumption of vitamin A rich foods was calculated as percent of households consuming either: vitamin A rich vegetables and tubers or dark green leafy vegetables or vitamin A rich fruits or organ meat, or eggs or milk and milk products. Consumption of iron rich food groups was calculated as percent of households consuming meat, or fish

$$
\frac{(\text { meat }+ \text { fish })}{\text { Sample size }} \times 100 \quad[15] \text {. }
$$

\section{Results}

\subsection{Household Information}

A cross sectional survey conducted in 39 villages, two locations, (Bukhayo East and Nambale Township) in Busia district, western Kenya involving 320 households (female $61.6 \%, 38.4 \%$ male) between $18-68$ years. A very high proportion $80.8 \%$ was within the youthful age range of 18 - 48 years unlike other studies [16] indicating age bracket $30-50$ as youthful years. Majority $90.4 \%$ of the respondents were married and the head of household (HH) was mainly father $90 \%$, with small percentage of mother, grandfather or grandmother and brother. Over half $52.4 \%$ of the households had between 6 and 10 members, while the lowest $2.2 \%$ had over 15 members.

\subsection{Child Information}

A total of 320 children were found but 88 were flagged off due to extreme age and SD leaving 232 eligible. The mean age for children was 33 months, mean weight 13.2 kilograms and mean height 88.3 centimeters with more female children than male (53.4\%:46.6\%) respectively and more children between 36 and 47 months.

\subsection{Nutrition Status of Children}

Nutrition status of children was poor, $(<-2$ SD and $<-3$ SD combined) stunting, underweight and wasting were $26.6 \%, 13.9 \%$, and $10.1 \%$ respectively, stunting slightly higher among female than male at $13.5 \%$ and $13.1 \%$ respectively. Male children were more underweight and wasting than female $7.8 \%: 6.1 \%, 5.1 \%: 5.0 \%$ respectively (Table 1). There was a negative but significant correlation between age of child and stunting, Pearson's R = -0.207 correlation sig. at the 0.01 level (2-tailed). Locations compared, significant associations were observed 
Table 1. Nutrition status of children by Gender.

\begin{tabular}{ccccccccc}
\hline \multirow{2}{*}{ Nutrition Status } & \multicolumn{2}{c}{ Normal $(>+2$ SD) } & \multicolumn{2}{c}{$\begin{array}{c}\text { Moderately Malnourished } \\
(<-2 \text { SD) }\end{array}$} & \multicolumn{2}{c}{$\begin{array}{c}\text { Severely Malnourished } \\
(<-3 \text { SD })\end{array}$} & \multicolumn{2}{c}{ Total \% } \\
\cline { 2 - 9 } & Male $\%$ & Female $\%$ & Male $\%$ & Female $\%$ & Male \% & Female \% & Male & Female \% \\
\hline Stunting N = 222 & 34.2 & 39.2 & 6.3 & 5.4 & 6.8 & 8.1 & 47.3 & 52.7 \\
Underweight N = 229 & 38.9 & 47.2 & 6.5 & $4.8 \%$ & 1.3 & 1.3 & 46.7 & 53.3 \\
Wasting N = 217 & 42.9 & 47.0 & 2.8 & 1.8 & 2.3 & 3.2 & 48.0 & 52.0 \\
\hline
\end{tabular}

for underweight among male children in Bukhayo at $\mathrm{p}<$ 0.001 and wasting among female children in Township at $\mathrm{p}<0.001$. Stunting in both locations was significantly associated with both female and male children at $\mathrm{p}<$ 0.001 using Pearson Chi Square Asymp Sign (2-tailed).

\subsection{Child Morbidity by Nutrition Status}

There were $41.8 \%(97 / 232)$ sick children at the study time and $90.21 \%$ had complete information for stunting, $92.15 \%$ for underweight and $89.24 \%$ for wasting. A high proportion, $72 \%$ of children who had been sick were not malnourished, stunting accounted for $28 \%$, underweight $15 \%$ and wasting $9 \%$. Severely stunted children who had been sick were $16 \%$ and this accounts for $45 \%$ (15/33) of all study children who were $<-3$ SD. There was no statistical significance $(\mathrm{p} \geq 0.05)$ between child morbidity and nutrition status as observed in other studies [17].

\subsection{Household Dietary Diversity (HDDS)}

A total of 2947 foods were consumed in 320 households over the 24 hour diet food recall with a mean HDDS of 9.2. Using FAO [15] dietary diversity score classification applied in Mozambique households had (96.8\%:2.4\%: $0.8 \%$ ) high, medium and low HDDS category respectively. Households which indicated main weaning staples as bananas, sweet potatoes, Irish potatoes and cassava were all in high HDDS category while those with maize and millet were in all three categories. There was no statistical significance between nutrition status of children and HDDS category.

\subsection{Main Sources of Protein, Carbohydrates and Vitamin A}

Main protein sources: milk 44.9\%, fish $38.5 \%$, legumes $13.4 \%$ and poultry $3.2 \%$. Location comparisons showed Township households had protein from all four sources, Bukahyo none had poultry. Main carbohydrate sources: maize $66.8 \%$, cassava $20.8 \%$ and this is similar to other studies [8]. Bukhayo had higher maize and Township higher cassava consumption, $74.8 \%$ and $38.4 \%$ respectively. Fruits, vegetables and fish were sources of vita- min A with the highest proportion (92.9\%) from vegetables. There was a high significant association between main source of carbohydrates, main source of vitamin A and utilization of cassava roots, $(p<0.05)$ and no association with protein.

\subsection{Nutrition Status, Source of Proteins, Carbohydrates and Vitamin A}

Households reporting milk and fish as main protein sources had each $40.7 \%$ stunting and more than half $55.9 \%(33 / 59)$ of these children were $<-3$ SD. Households reporting fish sources had almost half $43.8 \%$ of underweight children and of this category $15.6 \%(5 / 32)$ were $<-3$ SD. Majority, 91.7\% (11/12) severely wasting children were from households reporting fish and milk as main sources of protein.

\subsection{Main Staple for Weaning Children}

Eight staples were used for weaning and majority (44.9\%) used millet (Figure 1). Township had higher (81.1\%) proportion using millet, no bananas, cassava, rice or sorghum compared to Bukhayo where all staples were used. Pearson Chi-Square showed high significant relationships between "main staple for weaning children" and "education level of HH" and also "occupation of HH" (p $<0.001)$. "Main staple for weaning children" was also significantly related to "utilization of cassava" $(p<$ $0.001)$.

\subsection{Frequency of Child Feeding and Food Security}

The range for child feeding in a day was 1 to 6 times and majority $64.7 \%$ were fed three times followed by $19 \%$ fed four times irrespective of the age group. Majority $63.1 \%$, giving three feeds to children per day were in the high HDDS category. Pearson's $\mathrm{R}=0.178$ indicated a very significant positive correlation between number of feeds children were given and HDDS category $(\mathrm{p} \leq 0.01)$. More than half $(54.9 \%)$ of children fed three times a day belonged to households with 6 to 10 members and Bukhayo had a higher proportion feeding three times compared 


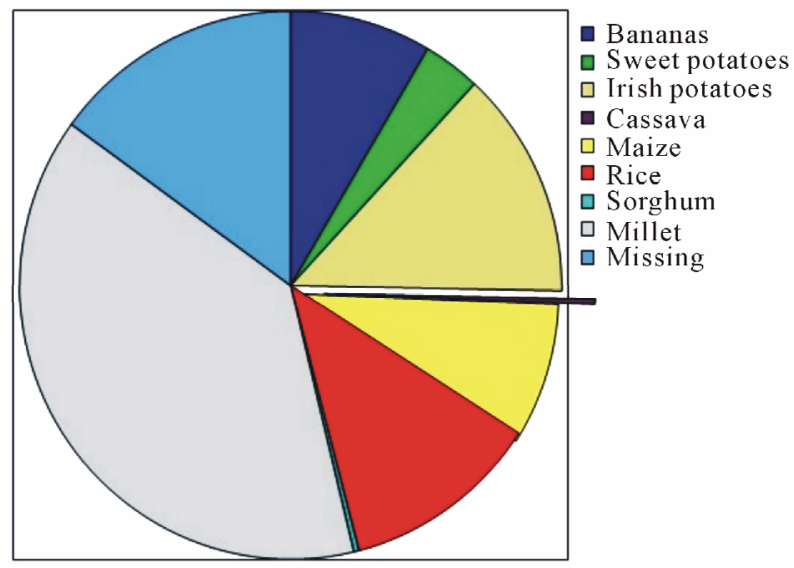

Figure 1. Main staple for weaning.

to Township (71.7\% and $60.3 \%)$ respectively.

\subsection{Socio-Economic Characterization}

\subsubsection{Education Level of Head of Household (HH)}

More than half $(59.1 \%)$ of the $\mathrm{HH}$ had some form of primary school education while $7.7 \%$ had no education, $8.9 \%$ had "secondary incomplete" and $23.6 \%$ had secondary complete and above. Combined stunting $(<-2 \mathrm{z}$ scores and $<-3 \mathrm{z}$ scores) were manifest in children irregardless of the category of education level of the HH. Households whose HH had incomplete primary level had the highest $(47.5 \%)$ proportion of stunting children. There was a significant but negative $(R=174$ correlation between education level of $\mathrm{HH}$ and nutritional status of children $(\mathrm{p} \leq 0.05)$.

\subsubsection{Land Ownership and Size}

Three quarters, $74.9 \%(\mathrm{n}=319)$, of the land was owned by $\mathrm{HH}, 24.1 \%$ ancestral and $0.3 \%$ was rented. $\mathrm{HH}$ with ancestral land ownership had majority $96.7 \%(57 / 59)$ of stunting children. Pearson's $\mathrm{R}=0.233$, showed strong positive significance between stunting and farm ownership indicating more than $50 \%$ of stunting could be linked exclusively to land ownership. Farm size ranged between $<1$ to $>20$ acres and majority $(71.7 \%)$ had $1-5$ acres while $2.7 \%$ had more than 20 acres. Pearson's $\mathrm{R}=$ 0.220 showed a positive significant correlation at 0.01 level (2-tailed) between farm size and education level of $\mathrm{HH}$ indicating more than $50 \%$ of the large land size was mainly due to education level of the $\mathrm{HH}$.

\subsubsection{House Roofing Material and Floor}

More than half, $55.9 \%(n=320)$, of the roofing material was corrugated iron while the rest, $44.1 \%$, had grass thatch. Majority, $83.8 \%(\mathrm{n}=320)$, of the floor were smeared with earth/mud/dung, $15.6 \%$ cemented and $0.6 \%$ had ceramic tiles. High proportions of stunting and underweight $54.2 \%$ and $53.1 \%$ respectively were from "corrugated iron" households while wasting from "grass thatch" 63.6\%. "Earth/mud/sand" floors had high proportions for stunting $88.1 \%$, underweight $93.8 \%$ and wasting $86.4 \%$. Roofing material and floor were not important determinants of the nutritional status just like in some previous studies [18].

\subsubsection{Dish Rack, Toilet and Bathroom}

More than half $60.2 \%(n=319)$ of the households had a dish rack for drying utensils, $12.7 \%$ had a soak pit for draining water. Toilet facilities were, traditional pit latrines (TPL), ventilated improved pit latrine (VIP) and no facility). TPLs were owned by $78.4 \%(n=320)$ of the respondents. More households in Township compared to Bukhayo had TPLs and no facility (80\%:76.9\%, 3.2\%: $1.3 \%$ ) respectively. Households with TPLs had majority of malnourished children, stunting $86.4 \%(\mathrm{n}=59)$, underweight $81.2 \%(\mathrm{n}=32)$ and wasting $59.1 \%(\mathrm{n}=22$. The bathroom facility was mainly a live natural enclosure used by $81.3 \%(\mathrm{n}=320)$. Majority of stunting $95.0 \%(\mathrm{n}=59)$, underweight $84.3 \%(\mathrm{n}=32)$ and wasting $77.2 \%(\mathrm{n}=22)$ were all from households that used enclosed natural wall. Stunting was significantly and positively correlated with bathroom facility, $\mathrm{R}=0.193$.

\subsubsection{Safe Water Provision}

Majority, $72.3 \%(\mathrm{n}=320)$, households used unsafe water and $39.4 \%$ spent less than five minutes to fetch water. Cross-tabulation for water supply source with nutrition status showed those using "spring" water to have high proportions of stunting, underweight and wasting $28.8 \%$, $28.0 \%, 40.9 \%$. Forty percent households with sick children used water from "spring". Water source was not found to be a determinant of nutrition status.

\subsubsection{Type of Cooking Fuel, Source of Firewood and Type of Cooking Stove}

Majority households, $97.8 \%(\mathrm{n}=318)$ used firewood for cooking and the main source of firewood was bush, $79.9 \%(\mathrm{n}=319)$. The three stone stove was the most popular $90.7 \%(\mathrm{n}=317)$. There was a very high significant relationship between wasting and "how firewood is obtained" ( $p \leq 0.001)$. Other studies [19] have shown the availability of fuel-wood to be a crucial link between food and nutrition status.

\subsubsection{Crops Grown on the Farm}

There was crop diversity and $76.9 \%(\mathrm{n}=320)$ grew cassava among other crops. The most popular crop combination consisted of: "maize, cassava, beans, bananas, sugarcane, kales, and fruits" and least popular; "maize, beans, palm oil, groundnuts, cassava, millet and bananas" 
(37.8\%:2.5\%) respectively. Crop combinations differed in the two locations and households with the least popular crop combination had no stunted children. There was no significant relationship between combination of crops and nutrition status. Nine varieties of cassava were grown as single variety or combination and most households grew a combination of "SS4, Migyera and Magana" while Migyera was most preferred for cooking (54.0\%:52.9\%) respectively. Magana was most preferred for processing while MM 96/5280 and Migyera were least processed traditionally.

\subsubsection{Cassava Utilization, Legumes Grown and Used by Households}

Cassava was utilized in three combinations, "for porridge, boiled roots, ugali" $94.3 \%,(\mathrm{n}=283)$, "porridge, boiled whole meal and roasted" $4.6 \%, 1.0 \%$ used "leaves as vegetables". This does not compare with myriad products mentioned elsewhere in other parts of Kenya [20]. Stunting, underweight and wasting had no statistical significant relationship with utilization of cassava, ( $\mathrm{p} \geq$ $0.05)$. Households grew and used, "cow peas and beans": "beans and soya beans":"beans, green grams and soya beans", $72.6 \%: 23.9 \%: 3.5 \%(\mathrm{n}=314)$. HH with cowpeas and beans had higher proportions for stunting, underweight and wasting 69.0\%:56.3\%:59.1\% respectively though there was no statistical significance, $(p \geq 0.05)$.

\section{Discussion}

\subsection{Nutrition Status}

The overall prevalence of stunting and underweight $26.6 \%: 13.9 \%$ were found to be in the medium range $(20 \%-29 \%: 10 \%-19 \%)$ respectively while wasting $10.1 \%$ was in the high range or serious $(10 \%-14 \%)$ acute global malnutrition as classified by WHO $[21,22]$. When compared with studies of 2008-2009 Kenya survey, stunting had decreased but wasting is higher than national average.

\subsection{Child and Environmental/Sanitation Characteristics}

Results from the study show malnutrition reached its peak during the third year of life affecting boys more than girls and this is similar to previous studies [2]. There were no cases of diarrhoea compared to other studies [17,23-25]. Female children suffered more from common cold and malaria while male suffered more from skin rashes. In this study children below six months were only fed between two and four times which is under feeding children who should be exclusively breastfeeding according to WHO recommendations. There were no malnutrition cases from households using "river or stream".
Child characteristics (age) and some environmental factors such as toilet and bathroom were found to be significant determinants of nutritional status similar to studies elsewhere [26].

\subsection{Household Dietary Diversity and Main Food Nutrient Sources}

Effects of variety in food choices on dietary quality are not obvious in this study due to high presence of malnutrition. Overall there is low consumption of animal source foods rich in iron and vitamin A rich foods (14.4\%:33.5\%) similar to previous studies in Kenya [27]. Households reporting maize had the highest percent stunting, underweight and wasting (71.2\%:78.1\%:72.7\%) respectively. Those reporting cassava as second carbohydrate choice had stunting, underweight and wasting at (18.6\%:9.4\%:9.1\%) respectively. Those consuming vegetables as main source of vitamin A had high proportions of stunting, underweight and wasting (89.8\%:81.2\%: $90.9 \%)$ respectively. No significant association was observed between nutrient variables and child nutritional status.

\section{Conclusions}

The high consumption of cereals and vegetables observed and the low consumption of both animal and vegetable proteins, indicate that children under-five years in this region are consuming inadequate diets deficient in nutrient quality and quantity.

Results from the study confirm cassava as an important carbohydrate in the diet of the community in Nambale. Another finding is that nutrition deteriorates with use of "enclosed natural bathing facility" indicating unhygienic environment conditions jeopardizing the health and nutrition status of children. Results also indicate nutrition decreasing in households that obtain firewood from "bush/forest" while using three stones as cooking stove.

\section{Recommendations}

Nutrient quality of cassava should be improved by blending with available protein and vitamin A foods or bio-fortification through breeding. "Enclosed natural bathing facility" should be addressed by public health to improve on the environment and sanitation conditions in which children are exposed. Firewood and efficient cook stove are important prerequisites for food preparation and can adversely affect nutrition status of children. The Ministries of Agriculture, Environment and Forestry should mount tree planting campaigns and use of fuel saving stoves involving all communities that use fire wood and three stones for cooking. 


\section{Acknowledgements}

The authors appreciate the support of: Ministry of Education, Science Research and Technology, Kenyatta Hospital Ethics Committee, Provincial Administration, Ministry of Agriculture, Ministry of Health, Ministry of Gender and Children, Ministry of Education, National Bureau of Statistics and all the farmers and their children who participated in the study.

\section{REFERENCES}

[1] L. Fedorov and D. E. Sahn, "Socioeconomic Determinants of Children's Health in Russia: A Longitudinal Study," Journal of Economic Development and Cultural Change, Vol. 53, No. 24, 2005, pp. 79-500.

[2] J. Kabubo-Mariara, G. K. Ndenge and M. K. Domisiano, "Determinants of Children's Nutritional Status in Kenya: Evidence from Demographic and Health Surveys," Journal of African Economies, Vol. 18, No. 3, 2009, pp. 363387. doi:10.1093/jae/ejn024

[3] UNICEF, "Statistics," In: State of the Worlds' Children, UNICEF, New York, 2008, pp. 57-60.

[4] R. Rutungwe, T. W. Oldewage, R. K Oniang'o and H. H. Voster, "Co-Existence of over and under Nutrition Diseases in Low Income, High Burden Countries," African Journal of Foods and Nutrition Sciences, Vol. 1, No. 200, 2001, pp. 34-42.

[5] Kenya Ministry of Health, "National Strategy on Infant and Young Child Nutrition," Nairobi, 2007.

[6] Central Bureau of Statistics (CBS), Ministry of Planning and National Development, "Kenya Integrated Household and Budget Survey, 2005-2006," Government of Kenya Printing Press, Nairobi, 2007.

[7] UNICEF, "How Likely Is a Poor Child to Be Underweight Compared to a Rich Child," State of the World's Children, UNICEF, New York, 2006, pp. 30-31.

[8] B. N. Ekesa, M. K. Walingo and M. O. Abukutsa-Onyango, "Influence of Agricultural Biodiversity on Dietary Diversity of Preschool Children in Matungu Division, Western Kenya," African Journal of Food, Agriculture, Nutrition and Development, Vol. 8. No. 4, 2008, pp. 390404.

[9] DAO, Busia District, "Kenya, Annual Crops Report," Ministry of Agriculture, Busia, 2006.

[10] Ministry of Planning and National Development (MOPND), "Busia District Development Plan 1997-2001," Government Printer, Nairobi, 1997.

[11] Z. Lukmanji, E. Hertzmark, N. Mlingi, V. Assey, G. Ndossi and W. Fawzi, "Tanzania Food Composition Tables," Muhumbili School of Health and Allied Sciences, Tanzania, 2008

http://www.hsph.harvard.edu/nutritionsource/files/tanzani a-food-composition-tables.pdf

[12] Central Bureau of Statistics (CBS), Ministry of Planning and National Development, "Rural Poverty Rates: Geographic Dimensions of Well-Being in Kenya: Where Are the Poor, Volume 1," Government of Kenya Printing Press, Nairobi, 2003.

[13] A. A. Fisher, J. F. Laing, J. E. Stoeckel and J. W. Townsend, "Handbook for Family Planning Operative Research Design," The Population Council, 1991.

[14] A. Swindale and P. Bilinsky, "Household Dietary Diversity Score (HDDS) for Measurement of Household Food Access: Indicator Guide," Academy for Educational Development, Washington, 2006.

[15] Food and Agriculture Organization (FAO), "Guidelines for Measuring Household and Individual Dietary Diversity," Version 3, Nutrition and Consumer Protection Division, EC/FAO Food Security Information for Action Programme and the Food and Nutrition Technical Assistance (FANTA) Project, Rome, 2007.

[16] S. O. Odebode, "Appropriate Technology for Cassava Processing in Nigeria: User's Point of View," Journal of International Women's Studies, Vol. 9, No. 3, 2008, pp. 269-283.

[17] P. A. Mahinda, "Child-Mother Nutrition and Nutrition Status in Kenya," International Journal of Consumer Studies, Vol. 30, No. 4, 2006, pp. 327-336.

[18] L. Christiaensen and H. Alderman, "Child Malnutrition in Ethiopia: Can Maternal Knowledge Augment the Role of Income?" Economic Development and Cultural Change, Vol. 52, No. 2, 2004, pp. 287-312. doi:10.1086/380822

[19] WFP, "The Availability of Fuel-Wood," Nutrition and the Environment, SCN News, No. 21, 2000, p. 84.

[20] E. E. Karuri, S. K. Mbugua, J. Karugia, K. Wanda and J. Jagwe, "Marketing Opportunities for Cassava Based Products: An Assessment of the Industrial Potential in Kenya, Market Study," Foodnet, Kampala, 2001.

[21] World Health Organization, "Global Database on Child Growth and Malnutrition," Geneva, 1997. http://libdoc.who.int/hq/1997/WHO NUT 97.4.pdf

[22] WHO, UNHCR, IFRC, WFP 2004, "The Management of Nutrition in Major Emergencies," Geneva, 2004. http://www.who.int/nutrition/publications/emergencies/a8 3743/en/index.html

[23] K. H. Brown, "Diarrhoea and Malnutrition," Journal of Nutrition, Vol. 133, No. 1, 2003, pp. 328S-332S.

[24] G. M. Mbagaya, M. O. Odhiambo and R. K. Oniang'o, "Mother's Health Seeking Behaviour during Child Illness in a Rural Western Kenya Community," African Health Sciences, Vol. 5, No. 4, 2005, pp. 322-327.

[25] K. C. Lutter and J. A. Rivera, "Nutritional Status of Infants and Young Children and Characteristics of Their Diets," Journal of Nutrition, Vol. 137, No. 2, 2007, pp. 484-487.

[26] N. Bomela, "Child Nutritional Status and Household Patterns in South Africa," African Journal of Food, Agriculture, Nutrition and Development, Vol. 7, No. 5, 2007, pp. 1-18. http://www.ajfand.net/volume7/No5/Bomela 2140.pdf

[27] N. O. Bwibo and C. G. Neumann, "The Need for Animal Source Foods by Kenyan Children," Journal of Nutrition, Vol. 133, No. 11, 2003, pp. 3936S-3940S. 